\title{
Determining Factors Of Bank Performance Based On Return On Solvency And Efficiency: A Study Of Turkish Banks
}

Begumhan Ozdincer, (Email: begumhan@bilgi.edu.tr), Bilgi University, Turkey Cenktan Ozyildirim, (Email: cenktan@bilgi.edu.tr), Bilgi University, Turkey

\begin{abstract}
The performance of the banking industry is analyzed by applying a panel regression on Turkish Bank data. Profitability is measured as revenues per unit of risk and efficiency as revenues per unit of cost. Return on solvency is used to measure the profitability using risk weighted assets as defined in the current Basel Accord. Both measures take into account the effect of the cost of capital to arrive at the real performance of the banks. The analysis is made using a panel regression between 2003:1 and 2005:2 analyzing 18 banks offering full-fledged services. The analysis of the short-term data leads to some striking results. The performance of banks is mainly driven by macroeconomic factors; banks rely on income from securities business to compensate for their poor results from their core activities which seems to be a result of the highly competitive environment. The analysis of efficiency reveals that market share is the most significant determinant. This result supports the idea that banks will be profiting from economies of scale and as they increase their market share they will be able to better utilize their excess capacity. The negative relationship between commission income and efficiency also strengthens our view that excess capacity is a problem of the industry and results in negligible commission income as opposed to high fixed costs for the service oriented banks.
\end{abstract}

\section{INTRODUCTION}

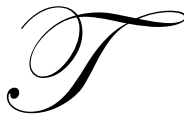

his paper analyzes the performance of banks in an emerging market by measuring profitability as revenues per unit of risk and efficiency as revenues per unit of cost. Revenues are taken net of cost of capital to reflect the true value added generated by the performance of the bank.

Performance measures that do not account for risk and cost of capital are far from reflecting true performance. In the 2000's, the banking industry is changing rapidly through increasing competition and the effect of advanced technologies. Meanwhile, banks are faced with enhanced standards and regulations to be able to compete on a global platform. The new Basel Accord which will be implemented in 2007 deals with the shortcomings of the existing system and puts forth more stringent rules on the minimum capital requirements in order to mitigate increased risk and moral hazard. This resulted in banks becoming more aware of the risks that are contained in the balance sheet. Performance measures incorporating risk, cost and cost of capital are becoming more relevant and are used more frequently in the industry. In this paper we measure performance by taking into account these factors in two performance measures; return on solvency and efficiency to analyze the true performance of banks.

We examine the performance of the banking industry by applying a panel regression on Turkish Bank data in the 2000's by examining bank level and macroeconomic variables. The performance of Turkish banks is studied for the period that started with a major restructuring of the financial system on the back of a macroeconomic stabilization program following decades of high volatility and hyperinflation. The nineties were unstable for the Turkish banking industry due to political and macroeconomic factors. As a result of this instability as well as mismanagement Turkey faced a financial meltdown at the beginning of 2001. The end of this period for the financial sector was marked by the 
liquidation of 22 Banks. The crisis was taken under control by severe macroeconomic measures under the IMF supervision.

In this context, this paper examines primarily the performance of banks taking into account their risk profiles by measuring their return on solvency using risk weighted assets as defined in the current Basel Accord. We measure return on solvency using revenues adjusted for the cost of capital and solvency calculated on risk weighted assets. During the period under study the banks reported quarterly total Risk Weighted Assets (RWA) calculated applying standard weights set by the Basel Capital Accord (1988) for classes of credit risks as well as market risk. Although far less refined than Basel II exposure calculations, RWA is the best available measure reflecting banks' risk position and clearly superior to other available variables like Total Assets or Total Credits. As such, for profitability measure we opt for using Return on Solvency (ROS) rather than Return on Assets (ROA) or Return on Equity (ROE). We also make a correction in the Risk Weighted Assets for the amount of public debt they carry on their balance sheet. According to the existing Basel Accord banks that buy public debt have to put aside $0 \%$ of their capital against them. However there is considerable vulnerability of banks to government default risk. Arnold, I. and Lemmen J (1999) examine the vulnerability of banks in EMU countries to shocks to default risk premiums on public debt and they conclude that one of the main reasons of this vulnerability is the total amount of public debt in bank portfolios as well as actual geographical diversification and therefore such risks can be reduced through proper diversification among public sector debtors.

Next we measure efficiency. Shareholders seek to maximize profits with the amount of risk they are willing to take. If a bank generates revenues at lower costs, it achieves higher profit margins than other banks. Therefore, we selected revenue/cost ratio as the most relevant and comprehensive scale for comparing efficiency across banks. In measuring efficiency the bank's revenues are adjusted for the cost of free capital. The adjustment for the free cost of capital is made to strip out the real performance of the banks.

The results indicate that Turkish Banks are undergoing a transition period whereby banks are fiercely competing to increase their market share mainly competing on price and compensating their losses by purchasing public debt. This is possible in a market where there exist considerable windfall profits from sharply falling yields.

The first section reviews the literature on research on performance of banks. The second section describes the methodology used the third section presents the results from the panel regression and the fourth section presents the conclusions that are drawn from the interpretation of the data.

\section{LITERATURE REVIEW}

Performances of banks have been mostly studied in the literature analyzing the effects of external factors like macro economic conditions/cycles in combination with bank level variables.

Demirgüç Kunt and Huizinga (1999) in their cross country comparison of bank profitability find that higher real interest rates and higher growth in real per capita GDP are associated with stronger bank profitability. Positive relationship between per capita output and bank profitability is consistent but their finding of a positive relationship between profitability and real interest rates is not in line with the findings of risk based studies. However, it can be argued that in periods of higher interest rates banks can earn higher interest rate spreads by taking on higher risks.

Kunt Levine and Beck (2003) investigate whether financial development and market structure of a country have an effect on the profitability of the banks and also the impact of financial development on bank profits and margins. They find that banks operating in different financial structures show differences in performance and that banks have higher profits and margins in underdeveloped financial systems and greater bank development lowers bank profits and margins.

Gizycki (2001) analyzes the variability in bank's credit risk and profitability by comparing the relative contributions of interbank variation and the variation through time to the overall variability in credit risk. The results show that impaired assets are strongly and positively correlated to the rate of real growth and the real interest rate. The 
paper argues that the aggregate demand and supply for loan finance will influence the riskiness and performance of the banking sector.

Flannery, M (1981) examines whether market interest rate fluctuations have a significant impact on profitability and his results show that large banks have effectively hedged themselves against market rate risk and therefore they are not necessarily vulnerable to market rate changes.

Jeon and Miller (2002) analyze the performance of foreign and domestic banks in Korea prior to during and after the Asian financial crisis and examine how the profitability of these banks differed and the identifying factors for these differences. Their results show capital adequacy ratio correlates positively with domestic bank performance measured as ROA and ROE. Decreases in foreign currency deposits significantly and negatively correlate with domestic bank performance. They find that higher loan loss provisions which signal the riskiness of banks associates negatively with bank returns. They also find that foreign banks consistently experience higher average returns on assets and equity.

Demirgüç and Huizinga (2000) examine whether financial development has an impact on bank profits and margins, they also investigate whether the financial structure of a market - whether it is bank based or market based makes an impact on the performance of banks operating after controlling for financial development. They use two measures of bank performance bank profitability and bank interest margins. They find that financial development has a very important impact on bank performance and that countries with underdeveloped financial markets have significantly higher levels of bank profits and margins. And once the level of financial development is controlled then there is no significant difference in bank profits or margins between bank-based or market-based systems. They also find that profits appear to decline with a greater proportion of non interest earning assets. Overhead is not found to be significant suggesting banks can fully pass on their non-interest expenses to their customers. Macro variables are mostly insignificant except for inflation which is significant and positive throughout.

Berger and Humphrey (1997) make a survey of the research on efficiency studies and some of their conclusions are that cost efficiency is more important than market concentration in explaining financial institution profitability however both variances weakly explain performance variation and also large banks tend to be more efficient on average than small banks which shows large banks benefit significantly from scale economies.

Bikker and Bos (2004) when they compare the cost-income ratios they find not correlated with most of the other measures and conclude this suggests it is an unreliable indicator of competition and inefficiency as a consequence of its ambiguous interpretation. As a conclusion of the empirical applicaton of the various models reviewed They state that competitive conditions have much more of an impact on the revenue side.

Berger and Mester (2002) investigate the effects of technological change, deregulation and changes in competition on the performance of US banks and their most prominent result is over time, as banks offered additional services or higher service quality which are difficult to control for in cost and profit functions, may have raised costs but also raised revenues by more than the cost increases resulting in measurement of worsened cost productivity but improved profit productivity.

Goddard, Molyneux, Wilson (2002) find market power to be a determinant of firm level performance. There is an inverse relationship between market share and profitability. Also macroeconomic performance appears to be a significant determinant of profit as well as growth as they find the coefficients on the GDP growth and Herfindahl index are positive and significant.

Several bank profit studies use proxies for risk including the capital assets and liquidity ratios to capture the notion that a bank's capacity to absorb unforeseen losses influences its overall performance. A relatively high capitalassets ratio could signify that a bank is operating over cautiously and ignoring potentially profitable diversification or other opportunities. Similarly a bank holding a high proportion of liquid assets is unlikely to earn high profits but is also less exposed to risk (Rhoades, 1985, Bourke 1989) 
Many studies show that bank performance is correlated with the business cycle. (Lowe and Rohling 1993; Kaylman 1998). An important point of discussion is how the new regulatory framework will impact macroeconomic stability. Quagliariello (2004) investigates the role of the business cycle in determining banks' performance by analyzing italian banks and checks to what extent loan losses, bad debt provisions and profitability are affected by bank specific variables and macroeconomic indicators. He finds that italian banks reduce their provisions when credit supply and gdp increase indicating procyclicality. He also argues that banks will become less prone to procyclicality after the implementation of the New Basel Accord. However, Zicchino (2005) states that the new system will augment the procyclical effects as the possibility during periods of weak economic growth, a fall in capital ratios and an increase in regulatory requirements implied by a deterioration in the risk profile of banks' assets might increase the likelihood of credit contraction and therefore a further weakening of growth.

There is also a wide literature that tries to identify bank level factors that best predict bank performance in the context of modeling and likelihood of bank failures. Arena (2005) investigates the systemic banking crisis and concludes that bank level fundamentals such as solvency, liquidity and asset quality are important for explaining cross country differences. He also concludes that bank level fundamentals not only significantly affect the likelihood of failure, but also explain a high proportion of the likelihood of failure for failed banks. Demirgüç-Kunt and Detragiache (1998) find that capital adequacy, earnings and impaired assets are the most useful indicators of the probability of failure.

Gonzales-Hermesillo Pazarbaşıoglu and Billings (1997) find during the analysis of the Mexican financial crisis that bank specific variables in combination with aggregate banking sector factors help to explain the likelihood of bank failure while macroeconomic factors play a major role in influencing the time of failure.

\section{METHODOLOGY}

In this research to assess the factors affecting the performance of the banking sector, we use a one-way error component panel data analysis. We have an unbalanced panel data which consists of 18 banks and 10 periods between 2002:1-2005:2. Using panel data provides notable advantages compared to ordinary least squares (OLS) method. First of all, it lets the researcher to evaluate the behavior of individuals over time. Second, it allows the researcher to control for individual heterogeneity. A typical panel data regression equation can be illustrated in the following form,

$$
y_{i t}=\alpha+X_{i t}^{\prime} \beta+u_{i t}
$$

where $\mathrm{i}$ denotes the cross section dimension and t denotes the time dimension. Most of the panel data analysis is developed on one-way error component model, in which the error term is defined as,

$$
u_{i t}=\mu_{i}+v_{i t}
$$

where $\mu_{i}$ is the unobserved individual specific effect, whereas $v_{i t}$ is the remainder disturbance. The second advantage of panel data analysis arises at this point. The omitted explanatory variables in a regression equation are collected in the error term. If the omitted variables are correlated with the explanatory variables in the model, error term turns out to be correlated with the explanatory variables, which violates one of the basic assumptions of the OLS.

The one-way error component model can be estimated by two different methods according to the structure of the unobserved effect. In the fixed effects model, unobserved effect is assumed to be a fixed parameter. To estimate the equation with OLS, we need to eliminate the unobserved effect. To wipe out the unobserved effect, the average equation for each group is calculated and then subtracted from the original observation. This transformation is known as within transformation, which basically uses time variation within each cross section. Fixed effect estimator then applies OLS to the transformed equation. 
The other method is random effects model, which assumes that $\mu_{i}$ is IID $\left(0, \sigma^{2}\right)$ and is not correlated with $v_{i t}$. Besides, the explanatory variables are assumed to be independent of unobserved effect and the remainder disturbance. Random effects estimation adds unobserved effect to the pooled OLS and is more restrictive compared to it. The superiority of random effects compared to pooled OLS is that it permits the serial correlation in the error term

$\left(u_{i t}=\mu_{i}+v_{i t}\right)$ in a generalized least squares (GLS) framework (Wooldridge, 2002). The variance-covariance matrix $(\Omega)$ in the GLS of one-way error model would have a homoskedastic variance on the diagonal,

$$
\operatorname{var}\left(u_{i t}\right)=\sigma_{\mu}^{2}+\sigma_{v}^{2}
$$

and serial correlation only between the disturbances of the same individual and zero otherwise,

$$
\begin{array}{ll}
\operatorname{cov}\left(u_{i t}, u_{j s}\right)=\sigma_{\mu}^{2}+\sigma_{v}^{2} & \text { for } i=j \text { and } t=s \\
\operatorname{cov}\left(u_{i t}, u_{j s}\right)=\sigma_{\mu}^{2} & \text { for } i=j \text { and } t \neq s \\
\operatorname{cov}\left(u_{i t}, u_{j s}\right)=0 & \text { otherwise }
\end{array}
$$

The FGLS estimator that uses the variance-covariance matrix $(\Omega)$ is defined as the random effects estimator,

$$
\beta_{R E}=\left(\sum_{i=1}^{N} X_{i}^{\prime} \widehat{\Omega}^{-1} X_{i}\right)\left(\sum_{i=1}^{N} X_{i}^{\prime} \widehat{\Omega}^{-1} y_{i}\right)
$$

The question at this point is which one to use in a panel data analysis; fixed effect or random effect model. The crucial difference between is the correlation assumption between the unobserved effect and the explanatory variables. Random effect assumes that there is no correlation between the unobserved effect and the regressors. Since within transformation wipes out the unobserved effect, this assumption is not required in fixed effects model. Baltagi (2001) states that in case of violation of no correlation assumption, wherein fixed effects model is appropriate, fixed effect estimator is best linear unbiased estimator (BLUE), whereas random effects estimator is inconsistent and inefficient. If random effects model is true, in other words no correlation between the unobserved effect and regressors holds, the random effects estimator is BLUE, whereas the fixed effect estimator is consistent but not efficient. One of the drawbacks of fixed effect estimator is that it wipes out time-constant variables, such as gender, sex and religion. To answer this question, Hausman test i used to check whether there exist a correlation between the unobserved effect and the explanatory variables.

\section{Measuring Performance}

In this study we focus on two performance measures; return on solvency and efficiency. Return on solvency measures return per unit of risk undertaken by the bank adjusted for the cost of capital and efficiency measures return per unit of cost incurred by the bank adjusted for the cost of available free capital of the bank. These two measures together are expected to provide an insight into the factors that will impact a bank's performance per unit of risk and per unit of cost. 


\section{Return on Solvency}

The most commonly used measures of competition and efficiency are ROE, ROA, the ratio of operating expenses to gross income and the interest rate margin ratio. In studies analyzing bank performance - ROE and ROA are used as measures of profitability. These profitability measures are based on the assumption that banks maximize profit without regard to risk. Two banks with the same profitability ratios would count as equally profitable and are considered otherwise identical even if one is riskier than the other. However, if banks maximize value rather than profit when the risk difference is priced by capital markets, the bank that does not manage risk as well will suffer a lower market value. (Hughes, Lang, Mester \& Moon, 1998).

In the Basel Capital Accord assets and off-balance-sheet positions are weighted at four standard factors ranging from $0 \%$ to $100 \%$ depending on the risks carried. Collaterals held to mitigate risks are also grossly taken into account, i.e. cash loans with mortgage on property would weight $50 \%$ versus a clean loan's weight of $100 \%$. For market risk resulting from changes in prices, interest rates, fx rates, etc., the positions are again weighted using standard rates taking into account the duration as well. Basel Accord does not give any risk weighting to government bonds. In this paper, all the government bonds (local currency and fx denominated) are given $100 \%$ risk weighting because in emerging countries government bonds can pose substantial default and interest rate risk and banks would seem to have a free ride on their zero risk weighted bond portfolio with high yields whereas they would seem to be punished on their lending activities.

Return on solvency measures the gross income of the bank adjusted for the cost of capital with respect to its risk weighted assets multiplied by the $8 \%$ standard required rate of solvency ratio according to the Basel Accord. The revenues are adjusted for interest on capital calculated at prevailing Government bond rates.

\section{Efficiency}

Advances in information technologies have transformed banking practices and products. Transactions costs have come down substantially, the sales potential of banks have increased through alternative distribution channels. Thus banks have been investing substantially in these advanced technologies in order to be able to compete better and increase their efficiencies.

Information technology has also contributed to the development of risk management systems and banks have become more aware and in control of the risks involved in the activities they undertake as well as taking on more calculated risk through the use of complex financial products.

The resulting increased competition forces banks to become ever more efficient. Merger activities have gained speed in developed markets such as the US and Europe in order to be able to deal with excess capacity and economies of scale. Davis and Salo (1998) state that consolidation maybe an efficient way to eliminate the widely documented excess capacity in European Banking Markets. Akhavein, Berger\& Humprey (1997) find that merged banks experience a statistically significant increase in profit efficiency rank relative to other banks. Hughes, Lang, Mester, Moon (1998) conclude that bank consolidation in the United States has improved banks' financial performance. Huizinga, Nelissen \& Vennet (2001) find that the cost efficiency of consolidating banks improves following a merger.

Bikker and Bos (2004) when they compare the cost-income ratios they find no correlation with most of the other measures and conclude this suggests it is an unreliable indicator of competition and inefficiency as a consequence of its ambiguous interpretation. As a conclusion of the empirical application of the various models reviewed they conclude competitive conditions have much more of an impact on the revenue side.

Operating expenses expressed as a percentage of gross income is often used as a proxy for measuring competitive conditions. This ratio in general is expected to fall over time, indicating lower costs compared to income. Given the falling interest rate margins, this would be pointing to cost reduction. Evidently, what is observed here are the efficiency effects of increased competitive pressure. However, banks may have the appearance of being highly 
efficient if they do not invest in advanced technologies or conversely stated those banks that are investing vigorously on technology may appear to be operating very inefficiently. Therefore measuring banks performance in terms of efficiency will yield much better results in the long term.

In this study, the efficiency measure used is the gross income of the bank adjusted for the cost of free capital with respect to the operational costs. To reach free capital we deduct from own means non-interest earning assets like fixed-assets, participations, non-performing loans, as well as non-cash revenue items.

The reason for adjusting the efficiency ratio for the cost of free capital available to the bank rather than the cost of total capital is because we aim to measure the operational efficiency regardless of the effect of balance sheet structure and capital strength resulting from past decisions and strategic choices. Some of these banks are heavily invested in non-interest earning assets and they would have a disadvantage against the banks who earn interest on their capital.

\section{Bank Variables}

Foreign Currency Liabilities

In Turkey, like in most Emerging Economies, local currency value displays high volatility rendering it riskier as a saving/borrowing currency, consequently funds change hands mostly at shorter maturities and at floating interest rates rather than longer tenors and fixed rates. This leads to currency substitution by local players, a tendency toward investing/borrowing in hard currencies rather than local currency.

The dollarization of the economy inevitably causes local banks to deal, to a great extent, in hard currency, in higher proportions than usually observed in developed markets. Depositors keep significant portion of their savings in hard currency, as a result majority of banks' liabilities are denominated in dollars. Similarly, corporates /individuals tend to borrow in hard currency since interest rates can be comparatively lower and more importantly longer term funds are available.

Therefore, banks carry significant balances in both on foreign currency assets and liabilities and it is crucial for them to keep their balance sheet mismatch under control in terms of currency type as well as maturity terms. Controlling currency mismatch is mostly within bank management's discretion, they manage their foreign currency lending in proportion to funds collected in the same currency. Banks can, from time to time, opt for running currency mismatches to benefit from arbitrage between local and foreign currency interest rates by borrowing in a hard currency and placing at higher interest rates of local currency while taking on the sharp devaluation risk. Such open currency positions are subject to limitations set by the watchdog in proportion to the capital base of the banks. However, a greater risk of volatility is carried by banks on duration mismatches between foreign currency assets and liabilities. This is imposed by the market as depositors by nature seek very short term maturities for their deposits whereas companies and individuals demand longer term funds for their financing needs. Banks, are in a way forced to carry the mismatch exposing them to liquidity risk and interest rate risk in case of a rally in interest rates.

Another aspect of the dollarized economy is that local parties, in the absence of local funds, tend to borrow in foreign currency although their businesses do not necessarily generate foreign currency inflows ie. non-exporting businesses. A shock devaluation will hit such companies adversely since their debts get larger in local currency terms while their receivables in local currency stay constant. This would ultimately effect bank performances, deteriorating credit quality and escalating loan losses.

\section{Doubtful Debts}

Banks report their doubtful loans as a separate asset item in their balance sheets. Specific provisions are made against those doubtfuls and reported as a deduction from debt balances. Therefore, what actually appears in the balance sheet is the net doubtful debtor balances. The provisions on the balance sheet are calculated on expected recovery rates of such loans where the watchdog sets the minimum required provisions based on certain criteria. 
Ratio of net doubtful debtor balances to total credits is a commonly used indicator to measure credit portfolio quality in banks.

However, to see the full picture in terms of the performance of the loan portfolio, the provisions for loans booked in the P/L should also be taken into consideration. Therefore, in this study, we compare the sum of the provisions expensed in the $\mathrm{P} / \mathrm{L}$ during the period and the increase in net doubtful balances in $\mathrm{B} / \mathrm{S}$ to total credits to reflect the total amount of credits that turn into doubtfuls /bad debts during the period. We believe this is more reflective of the quality of the loan portfolio.

\section{Government Bond Portfolio}

This ratio measures the ratio of government bonds to total liabilities. Local Banks inherently keep significant balances in sovereign paper. Liquidity reserves, legal reserves and cash collaterals for local market transactions are mostly kept in local treasury securities. Governments running budget deficits and high borrowing levels pay high real interest rates to rollover their borrowings. At times, yield on these papers can be so attractive that banks tend to invest much more than call of their business/legal requirements. The risk born in sovereign securities denominated in local currency is considered lower since transferability and convertibility is not an issue and the issuer has the ability to print money as a last resort therefore default risk is considered low.

Such high interest rates paid by the government are an alternative to bank deposits and therefore banks inevitably offer similar rates in deposits not to lose their deposit base. The only way to offer competitive rates for banks is to invest funds in government paper with longer maturity to attract shorter term deposits. This results in banks taking on maturity mismatch risk, higher risk of government default and a less diversified portfolio.

The government's total borrowing requirement measured against GDP is a commonly used indicator by the markets in pricing the sovereign risk. When sovereign is required to borrow heavily and keep rolling high levels of debts, markets demand higher interest rates. Such borrowing levels can be so overwhelming for the local market that it can lead to crowding out effect leaving private companies and individuals in a credit squeeze and leading to a sharp increase in interest rates.

\section{Commission Income}

Commission income is the ratio of commission income to total income. This item, to a great extent, is composed of commissions collected from banking services offered. In a competitive environment in order to collect commissions for services, the banks must offer comparatively better services since some banks will waive charging commission just to keep their customers and not to lose their market share. Therefore, a higher ratio can be seen a sign of advanced technology and enhanced process flows to enable banks to offer better services than the competition.

\section{Credits To Third Party Funds}

The ratio of credits to third party funds is reflecting risk appetite better than credits to total liabilities ratio as banks may have differing levels of capital base and tend to keep their capital in sovereign paper and liquid assets to a great extent rather than lending. The third party funds are, however expected to be mostly turned into credits after earmarking for buffer and liquidity. We typically see in conservative banks that a bigger portion of collected funds are kept in T-bills and/or in deposits with highly credible banks.

\section{Market Share}

Banking is by nature a costly operation due to high regulatory requirements as well as stiff competition calling for continuous and ever increasing investment in people, systems, distribution channels etc. To justify such overhead costs banks need to reach economies of scale in terms of their business volumes. Therefore, banks target higher market share leading to higher transaction volumes and revenues to improve their efficiency. 
This ratio measures the market share of the bank with respect to the sample group. We assumed that the best measure for market share is the share of deposits of the bank to the total deposits of the sample group. This is also the general market view and perception of the banks themselves so that deposit rates offered by the banks are shaped under fierce competition. This may be fueled by the high level of government guaranty/insurance on deposits so that depositors are usually indifferent to the riskiness of banks.

\section{Macroeconomic Variables}

\section{Treasury Bond Rates}

Interest rates on government securities can effect bank performance in various ways. Since significant balances are kept in government securities the impact of the general level of sovereign interest rate is substantial on the revenue of banks. Similarly, mark-to-market effect of interest rate changes on the existing portfolio can be high and reflected to $\mathrm{P} / \mathrm{L}$ either immediately or gradually depending on the treatment of the portfolio. Another major impact of treasury bond rates is due to the calculation of cost-of-capital and free capital where market average of government paper interest rates are used as the risk free rate.

GNP In Terms Of USD

The level of activity in an economy is an indisputable factor affecting the operations and performance of the banking sector. An economic growth means an increase in the expenditure and investments which would lead to an increase in the money circulation and demand. In turn, this leads to the increase in credit and deposit volumes, and accordingly higher profitability and efficiency for the banking sector. This issue is more significant for the developing economies such as Turkey, where banking sector is by far the dominant intermediary in the financial markets. Therefore, in this model we predict positive effects of the GNP on the financial performance measures of the banking sector.

\section{EMPIRICAL FINDINGS}

This section presents the results on the relationship between bank performance as measured by return on solvency and efficiency and bank variables and macro variables. Figures 1-3 provides the charts for trends for the dependent and bank specific variables. We divide the banks into three sizes as large medium and small. Those with a market share of $10 \%$ and higher are in large banks category, $3 \%-9 \%$ medium sized and $2 \%$ and lower are in the small banks category. There are 4 banks in the first group, 6 in medium and 8 in the small size group.

Next, we study these relationships using a linear regression model.

The results for fixed and random effects are presented in Table 1 and Table 2 for efficiency and return on solvency. The results of the Hausmann test are rejected for random effects and therefore are considered inconsistent and not analyzed. 


\begin{tabular}{|c|c|c|}
\hline \multicolumn{3}{|c|}{ Table 1: Efficiency Ratio Estimators } \\
\hline & Fixed Effect Estimator & Random Effect Estimator \\
\hline \multirow[t]{2}{*}{ Doubtful Debt } & 2.465 & 1.611 \\
\hline & $(1.947)$ & $(2.035)$ \\
\hline \multirow[t]{2}{*}{ Credits to $3^{\text {rd }}$ party funds } & -0.481 & -0.024 \\
\hline & $(0.57)$ & $(0.453)$ \\
\hline \multirow{2}{*}{ Government Bonds/TL } & -0.364 & 0.417 \\
\hline & $(0.639)$ & $(0.519)$ \\
\hline \multirow[t]{2}{*}{ FX Lia. $/ 3^{\text {rd }}$ party funds } & -0.787 & -0.1458 \\
\hline & $(0.679)$ & $(0.49)$ \\
\hline \multirow[t]{2}{*}{ T-Bond Real Int. rates } & 0.306 & 0.249 \\
\hline & $(0.393)$ & $(0.391)$ \\
\hline \multirow[t]{2}{*}{ GNP in USD } & 0.0001 & 0.0001 \\
\hline & $(0.001)$ & $(0.001)$ \\
\hline \multirow[t]{2}{*}{ Commission/Gross Income } & -0.355 & -0.273 \\
\hline & $(0.18) * * *$ & $(0.18)$ \\
\hline \multirow[t]{2}{*}{ Market Share } & 30.855 & 4.061 \\
\hline & $(6.223)^{*}$ & $(0.893)^{*}$ \\
\hline
\end{tabular}

The adjusted $\mathrm{R}^{2}$ of the regression is $48.26 \%$. The most significant variable that explains efficiency is market share. Efficiency increases with market share. The revenue cost ratio adjusted for the cost of free capital is highest for those banks with a larger market power as measured by the ratio of deposits to total deposits. This result is in line with other research on efficiency in banking industry as previously mentioned and provides support for banks' fierce competition for increasing their market share through acquisitions and other means.

We observe a negative correlation between efficiency and commission income contrary to our initial expectations. The results imply that banks that have low commission income have high efficiency and those that have high commission incomes have low efficiency. The service oriented banks are able to charge higher fees for the competitive services they provide and therefore their commission incomes are higher. These banks invest substantially in infrastructure, advanced technologies and IT systems and therefore their cost base is quite high. However, for these banks incremental revenues generated thanks to these investments are not sufficient to compensate for the negative effect of these investments/expenses on the efficiency ratio. This is firstly, due to excess capacity in the sector and lack of economies of scale in business turnovers. Secondly, due to severe competition among banks. Certain banks can go as far as offering such services free of charge just to keep their market share.

On the other hand, the banks that cannot offer competitive services cannot charge their clients for these services. These banks do not spend on technology, infrastructure, and other resources keeping their costs under control and bearing in mind that commission income can only be a lower percentage of total income without any major contribution to their performance in the short term.

Therefore, the negative correlation between these two measures is an indication that if banks do not invest in providing competitive services and thus have low commission income and provide services at lower cost are better performers in the short-term. This is possible as long as banks are able to compensate for lower commission income by income in other areas such as from high yielding government bonds.

Commission income generated on competitive services/products presents higher customer loyalty and better cross selling opportunities which would pay off in the longer term. Thus, we may conclude that even though banks that have high commission income compared to their total income have lower efficiency ratios in the period analyzed, the sustainability of their commission income improves their earnings quality and these banks should be expected to reap the benefits in the longer term as interest rate margins on government bonds and credit spreads continue to squeeze with increased competition where banks have no other option but to increase their services income or consolidate their businesses with other banks. The ratio of credits to third party funds is not significant and so is the ratio of government bonds. 


\begin{tabular}{|c|c|c|}
\hline \multicolumn{3}{|c|}{ Table 2: Return On Solvency Estimators } \\
\hline & Fixed Effect Estimator & Random Effect Estimator \\
\hline \multirow[t]{2}{*}{\begin{tabular}{|l|} 
Doubtful Debt \\
\end{tabular}} & -0.582 & -0.6997 \\
\hline & $(0.454)$ & $(0.454)$ \\
\hline \multirow[t]{2}{*}{ Credits to $3^{\text {rd }}$ party funds } & -0.357 & -0.202 \\
\hline & $(0.133)^{*}$ & $(0.117) * * *$ \\
\hline \multirow[t]{2}{*}{ Government Bonds/TL } & -0.038 & 0.025 \\
\hline & $(0.149)$ & $(0.133)$ \\
\hline \multirow[t]{2}{*}{ FX Lia. $/ 3^{\text {rd }}$ party funds } & -0.253 & -0.1694 \\
\hline & $(0.159)$ & $(0.131)$ \\
\hline \multirow[t]{2}{*}{ T-Bond Real Int. rates } & -0.237 & -0.214 \\
\hline & $(0.092) * *$ & $(0.09)^{* *}$ \\
\hline \multirow[t]{2}{*}{ GNP in USD } & 0.0001 & 0.0001 \\
\hline & $(0.001)$ & $(0.001)$ \\
\hline \multirow[t]{2}{*}{ Commission/Gross Income } & -0.131 & -0.151 \\
\hline & $(0.042)^{*}$ & $(0.041)^{*}$ \\
\hline \multirow[t]{2}{*}{ Market Share } & -0.15 & -0.635 \\
\hline & $(1.451)$ & $(0.298)^{* *}$ \\
\hline
\end{tabular}

The adjusted $\mathrm{R}^{2}$ of the regression is $58.13 \%$.

The results on return on solvency are reported on Table 2. According to these results return on solvency has a negative correlation with the ratio of credits to third party funds, treasury bond rates and commission income.

The negative correlation between return on solvency and government bond rates is expected. At the beginning of the period analyzed the government bond rates were a high of $58 \%$ and come down to $16 \%$ level on an annual basis in the last quarter of the period analyzed. Despite the fact that we adjust the return for the cost of capital at prevailing T-bill rates, the Turkish Banks increased their gross returns during this period by realizing mark to market profits as well as trading profits on their treasury bond portfolio and this probably is by far the single most important determinant of their gross return.

The effect of mark-to market return on government bonds is so overwhelming that there is a significant and negative correlation between return on solvency and loans to third party funds. Under normal circumstances, it would be expected that as banks give out more loans they increase their returns. However, the fact that the relationship is opposite brings forth several possible explanations. First, it may be that the banks are giving out loans with narrower spreads which makes the business much less attractive compared to investing in government bonds where the spreads are higher. This makes it look as if banks are much better off investing in high yielding government paper rather than loaning money. The high yields subsidize lower yielding loan business which helps banks to increase their share in the loan market. However, given that the return on government paper is not sustainable, they cannot continue this behavior in the medium term and should resort to their core banking activities as the markets normalize.

The other possible explanation as to the negative correlation between return on solvency and credits is that banks that give out high amounts of loans are those that have traditionally been taking on more credit risk and therefore those that have mostly been affected by the macroeconomic crisis during 2001 when they have lost substantial amounts of their capital on bad loans. As such, as we adjust the gross return for the cost of capital for these banks, they are charged for the cost of capital although their free capital is small or even negative so they are disadvantaged against other banks with more free capital because they are deprived of capital to invest into government securities and gain mark-to market profits. In short, the negative relationship between ROS and Loans can be attributed to the negative effects of the 2001 crisis which can still be traced from the banks' balance sheets.

In line with our explanation for the relationship between return on solvency and credits and considering the fact that the banks that give out high loans are usually the service-oriented banks that are able to charge high commissions for their services, their low return on solvency due to their bad credit history gives the appearance of a 
false relationship that commission income has a negative impact on return on solvency whereas the fact is that those banks that are able to charge high commissions are those that have a low return on solvency due to their lack of ability to earn market interest rates on their capital.

In the short-term, the analysis of the data on Turkish banks implies that return on solvency is to a great extent shaped by falling interest rates. Furthermore, banks try to compensate for lack of service charges and thin spreads on loans by gains in treasury paper just to be able to increase/maintain their market share. These results should be expected to reverse when the effects of this one time windfall profits from government paper disappear and banks are obliged to make money from their core banking activities. As such the relationship between return on solvency and credit levels and commission income should be normalized.

\section{CONCLUSION}

This paper analyzes the performance of banks in an emerging market by measuring profitability as revenues per unit of risk and efficiency as revenues per unit of cost. Return on solvency is presented in this paper as a better way of measuring profitability compared to other profitability ratios such as return on equity or return on assets because it incorporates the risk factor. Furthermore, the performance measures used in this paper are also different in that they account for the cost of capital in both measures to arrive at the real banking performance of the bank.

The analysis of this short-term period of Turkish banks' performance leads to two striking results. The first is that after accounting for the cost of capital, we find that return on solvency is mainly driven by the falling market interest rates. Banks seem to be performing poorly on their activities. They rely on their non core banking activities i.e. trading securities for improving the situation. And the second result is that efficiency is negatively related to commission income even though our initial expectations were on the contrary. The main reason being that the fierce competition in the industry forces them to offer services at very low or no charges and those who invest in offering better services and thus incur high costs are faced with the problem of a much lower efficiency ratio due to the incongruity between their commission income and the costs they incurred to achieve this income and excess capacity. The second conclusion supports our first conclusion and that banks are able to trade off their income from banking activities against keeping their market share as long as they can compensate their losses from their securities portfolio.

Even though the Turkish Banking Industry has seen some consolidation there are still quite a number of banks whose market share is around $1 \%$. It looks as if these banks are able to survive on their non-banking activities because the amount of core banking revenues such as loans and services compared to purchasing securities is insignificant. This situation also enables them to trade off their income on their core business as a means of investing in the medium and longer term by foregoing any revenues on these activities and instead trying to increase their market share by compensating for these losses through their securities income and in a way investing in their long term viability. By taking advantage of this abnormal market circumstances they expect to become attractive merger partners with their increased market share.

The analysis of efficiency reveals that market share is the most significant determinant of efficiency. This result also supports the idea that banks will be profiting from economies of scale and as they increase their market share they will be able to better utilize their excess capacity which also points to the expectation of more consolidation in the medium term. The negative relationship between commission income and efficiency strengthens our view of the excess capacity in the industry, however, this negative relationship does not take into account the quality of the earnings which is more vital for the longer term. We expect that as market circumstances change and the windfall profits from purchasing securities disappear then the real effect of sustainable income on efficiency will become apparent.

The shortness of the period analyzed poses several problems. Primarily, there is very little fluctuation in the markets during the period analyzed which prevents us to be able to witness the negative effects of their undiversified asset portfolio in a market downturn which would make them highly vulnerable to default risk or an interest rate 
shock. Also, the effects of the transition period will gradually disappear and we expect that the results we find in this short term period will be reversed in the longer term.

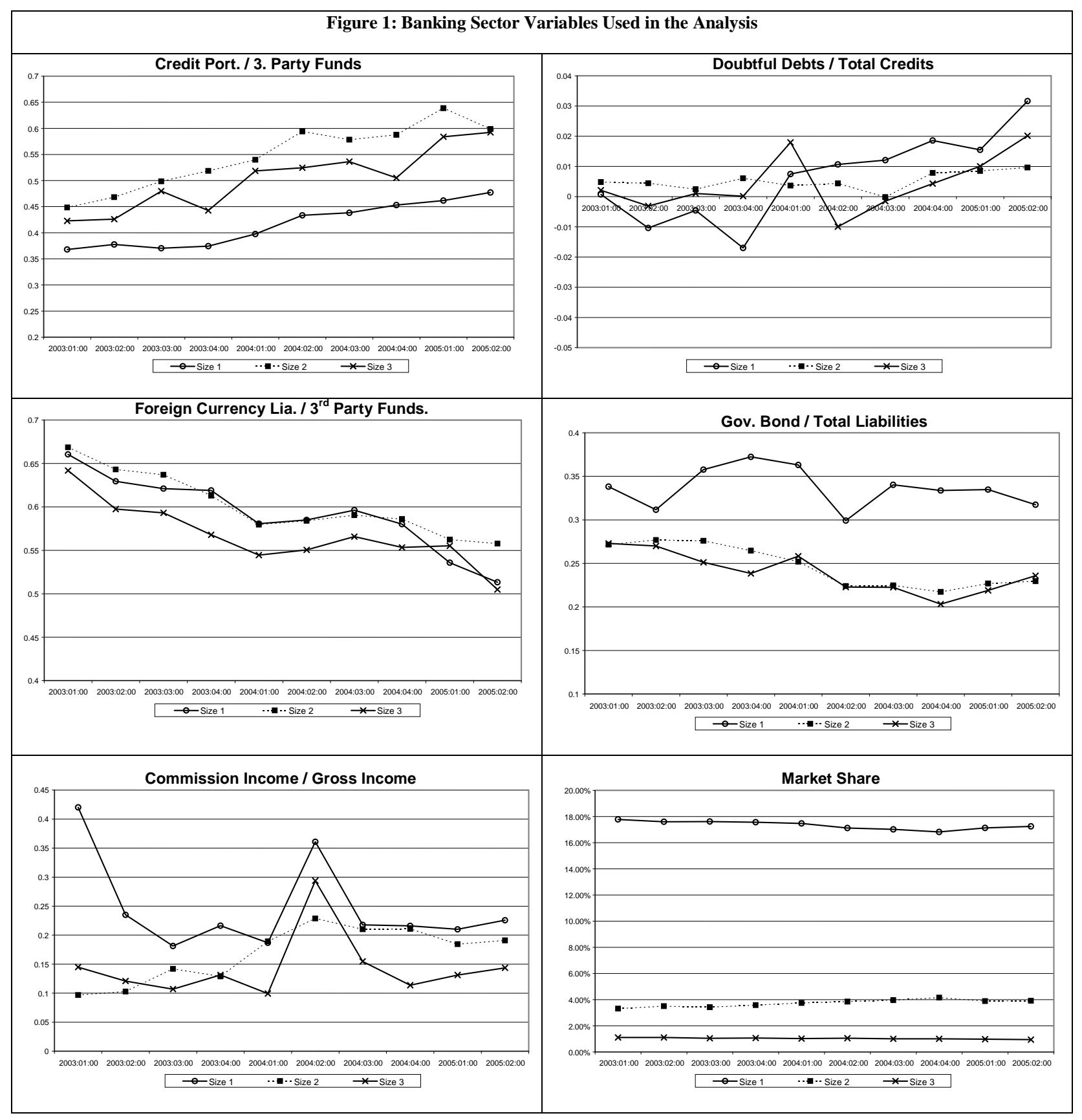

Figure 2: Dependent Variables 

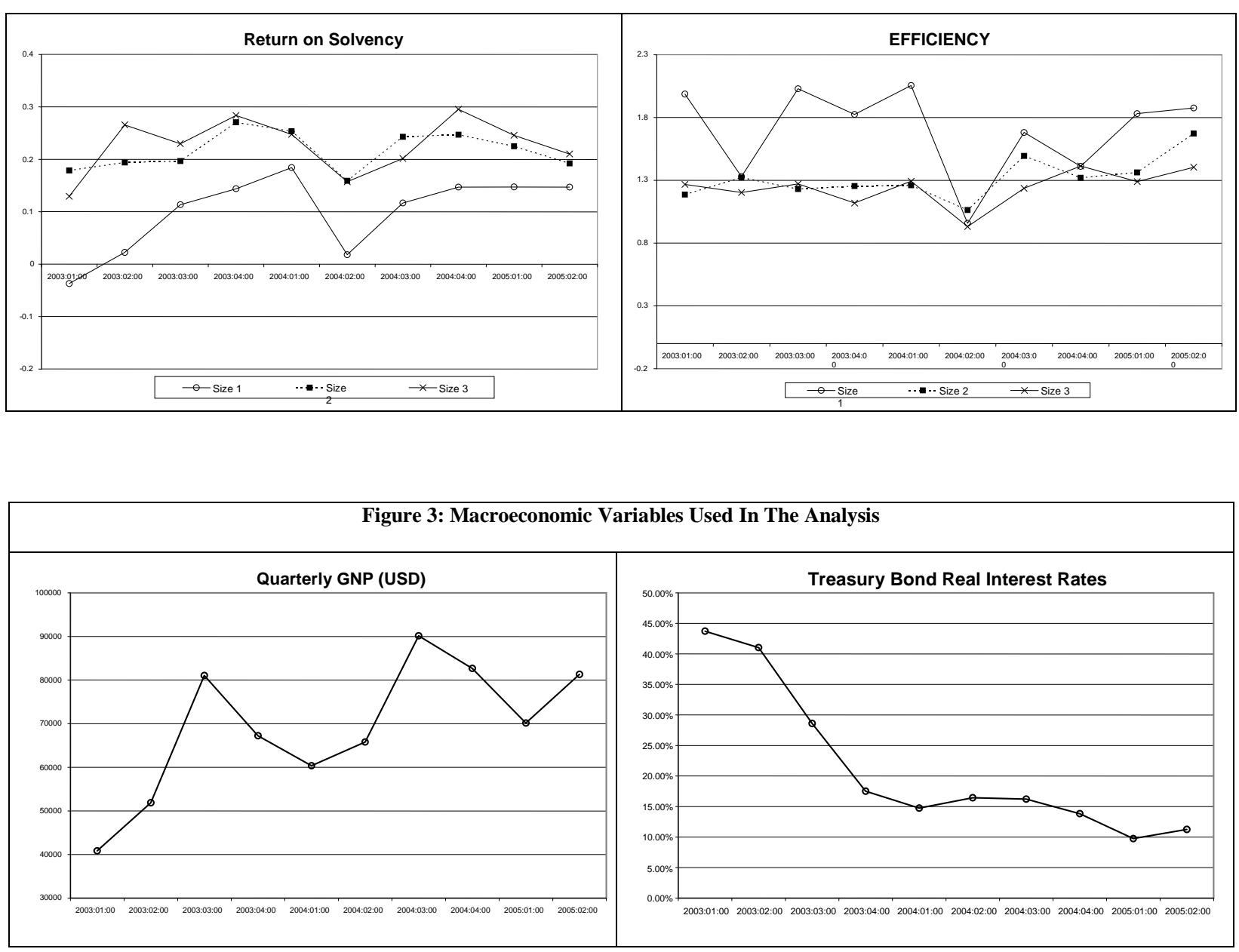

\section{REFERENCES}

1. Akhavein, J.D., Berger A.N, and Humphrey, D.B., (1997) The Effects of megamergers on efficiency and prices; Evidence from a bank profit function, (1997) Forthcoming, Review of Industrial Organization, Vol.12, 1997.

2. Arena, M. (2005), Bank failures and bank fundamentals: A comparative analysis of Latin America and East Asia during the nineties using bank level data, Bank of Canada, Working paper.

3. Arnold, I.J.M. and Lemmen J., (1999), The Vulnerability of Banks to Government Default Risk in the EMU, LSE Financial Markets Group Special paper No.115.

4. Berger, A., and Mester, L.J., (2002), Explaining the Dramatic Changes in performance of U.S.Banks: Technological Change, Deregulation, and Dynamic Changes in Competition, Federal Reserve Bank of Philadelphia, Working Paper No.01-6/Ra.

5. Berger, A. N. and H.B., (1997), Efficiency of Financial Institutions: International survey and directions for future research, European Journal of Operations Research, 98, 175-212.

6. Bikker, J., Bos, J. and (2004), Trends in Competition and Profitability in the Banking Industry: A Basic Framework, DNB Working Papers, No 018.

7. Davis, E. P. and S. Salo, (1998), Excess capacity in EU and US banking sectors: Conceptual, measurement and policy issues, LSE Financial Markets Group Special paper No.105.

8. Demirgüç-Kunt A. and H. Huizinga, (1999), Determinants of Commercial Bank Interest Margins and Profitability: Some International Evidence, The World Bank Economic Review, 13(2), pp 379-408. 
9. Demirgüç-Kunt, A.,and Huizinga H, (2000), Financial Structure and Bank Profitability Policy research working paper.

10. Demirgüç-Kunt, Detragiache, E. (2005), Cross Country Empirical Studies of Systemic Bank Distress:A Survey, IMF Working Paper

11. Demirgüç-Kunt, Levine, and Beck, (2003), Bank Concentration and Crises, NBER Working paper series, 9921

12. Flannery, M., (1981), Market Interest Rates and Commercial Bank Profitability: An Empirical Investigation, Journal Of Finance, Vol. 36, No.6.

13. Gizycki., M., (2001), The Effect of Macroeconomic conditions on Banks Risk and Profitability, Discussion Paper.

14. Goddard J., Molyneux P., and Wilson, O.S.J., (2004), Dynamics of Growth and Profitability in Banking, Journal of Money Credit and Banking, Vol.36, No.6.

15. Gonzales- Hermosillo, B., C. Pazarbaşıoğlu and R. Billings, (1997), Determinants of Banking System Fragility: A Case of Mexico, IMF Staff Papers 44(3) pp 295-314.

16. Hughes, J.P., Lang, W., Mester, L.J., and Moon, C.G. (1999), The Dollars and Sense of Bank Consolidation, Working Paper, University of Pennsylvania.

17. Huizinga, H.P., Nelissen, J.H.M., and Vennet, R.Vander, (2001), Efficiency Effects of Bank Mergers and Acquisitions in Europe, Working Paper, Tinbergen Institute Discussion Paper

18. Jeon, Y. and Miller M. Stephen, (2002), The Performance of Domestic and Foreign Banks: The Case of Korea and the Asian Financial Crisis, working paper.

19. Quagliariello, M., (2004), Banks Performance over the Business Cycle: A Panel Analysis on Italian Intermediaries University of York, discussion papers in economics.

20. Zicchino, L., (2005), A model of bank capital, lending and the macro economy: Basel I versus Basel II, Bank of England working paper.

\section{NOTES}

